\title{
The cAMP-ERK1/2 signaling pathway regulates urokinase- type plasminogen activator-induced bovine granulosa cell proliferation
}

\author{
Yufen Zhao ${ }^{1,2, *}$, Boyang Yu ${ }^{3, *}$, Xinyu $\mathrm{Liu}^{1,2, *}$, Jitu Hu${ }^{1,2, *}$, Yanyan Yang ${ }^{4}$, Erge Namei ${ }^{1,2}$, \\ Bingxue Yang ${ }^{1,2}$, Yue Bai ${ }^{1,2}$, Yinghong Qian ${ }^{5}$ and Haijun Li®i ${ }^{1,2}$ \\ ${ }^{1}$ College of Veterinary Medicine, Inner Mongolia Agricultural University, Hohhot, China, ${ }^{2}$ Inner Mongolia Key \\ Laboratory of Basic Veterinary Science, Inner Mongolia Agricultural University, Hohhot, China, ${ }^{3}$ Basic Medical \\ College, Inner Mongolia Medical University, Hohhot, China, ${ }^{4}$ Institute of Animal Husbandry, Inner Mongolia \\ Academy of Agricultural and Animal Husbandry Sciences, Hohhot, China and ${ }^{5}$ Inner Mongolia of Agricultural and \\ Animal Husbandry Science, Hohhot, China \\ Correspondence should be addressed to H Li; Email: navy1973@163.com
}

*(Y Zhao, B Yu, X Liu and J Hu contributed equally to this work)

\begin{abstract}
Although urokinase-type plasminogen activator (PLAU) and urokinase-type plasminogen activator receptor (PLAUR) have been reported to play key roles in ovarian function, their precise contribution to mammalian follicular development remains unclear. In this study, we first observed that PLAU and PLAUR were present in bovine granulosa cells (GCs). Following culture of granulosa cells with PLAU (0.5 $\mathrm{ng} / \mathrm{mL})$ and PLAUR antibody $(10 \mu \mathrm{g} / \mathrm{mL})$ separately and together for 24 or $48 \mathrm{~h}$, a proliferation assay showed that interaction between PLAU and PLAUR contributes to bovine GC proliferation. To study the potential pathways involved in PLAU/ PLAUR-induced cell proliferation, ELISA and Western blotting were performed. We found that PLAU significantly increased the ratio of phosphorylated to non-phosphorylated ERK1/2 through PLAUR signaling. Further treatment with U0126, a specific ERK1/2 phosphorylation inhibitor, markedly suppressed PLAU/PLAUR-induced ERK1/2 phosphorylation and cell proliferation. In addition, we found that PLAU and PLAUR significantly increased the intracellular cAMP level and the use of Rp-cAMP, a specific PKA inhibitor, prevented PLAU/PLAUR from promoting activation of the ERK1/2 pathway and GC proliferation. Therefore, the interaction between PLAU and PLAUR may be involved in accumulating cAMP signals and enabling MAPK/ERK1/2 activation, affecting GC proliferation. Here, we provide new mechanistic insights into the roles of PLAU and PLAUR on promoting bovine GC proliferation. The finding that potential cross-points between PLAU/PLAUR-induced intracellular signals affect GC proliferation will help in understanding the mechanisms regulating early follicular development.

Reproduction (2020) 160 853-862
\end{abstract}

\section{Introduction}

Urokinase-type plasminogen activator (PLAU) is a serine proteinase that catalyzes the transformation from plasminogen to plasmin when activated by binding it to its receptor (urokinase-type plasminogen activator receptor, PLAUR), which is linked to the cell surface via a glycosyl-phosphatidylinositol (GPI) tail (Wu et al. 2014). This process plays key roles in cellular invasion and tissue involution during normal physiological processes and during metastasis of tumor cells (Ossowski et al. 1979, Liu \& Rabbani 1995). In recent years, it has been reported that PLAU and its receptor have a potential role in the ovulatory process. For example, PLAU and PLAUR mRNA levels and PLAU activity in bovine preovulatory follicles increased in response to the gonadotropin surge (Dow et al. 2002). In addition, intrafollicular injection with PLAU antibody disrupted the ovulatory process, indicating that PLAU is obligatory for ovine follicle rupture (Colgin \& Murdoch 1997). However, an opposite conclusion has been drawn by other researchers (Li et al. 1997), who recognized PLAU as an important regulatory factor at early stages of follicular development rather than at ovulation. This was based on findings that PLAU activity was present only in cultures of undifferentiated, proliferatively active granulosa cells and not in differentiated cells (Li et al. 1997). It was further supported by the observation that LH markedly suppressed PLAU activity in hen preovulatory follicles (Tilly \& Johnson 1987). Thus, the species-specific and cell-specific regulation of PLAU and PLAUR need to be well-established in order to understand their exact 
contribution to the follicular growth or ovulatory processes.

In the mammalian ovary, oocytes reside within the follicles and are surrounded by granulosa cell (GC) layers. The proliferation and terminal differentiation of GCs are critical for normal follicular growth, ovulation, and luteinization (Robker \& Richards 1998). It has been reported that GCs have different mitogenic potential in relation to the size of follicles. Compared with the GCs obtained from large follicles, small follicular GCs are more proliferative (Bartholomeusz et al. 1988). During follicular development, the formation and enlargement of an antrum is accompanied by GC proliferation to allow fluid to accumulate, which is a feature of mammalian ovarian follicular growth (Li et al. 1997, Rodgers \& Irving-Rodgers 2010).

Previous evidence indicated the expression of PLAU and PLAUR in a great variety of cell types, including endothelial cells (Stepanova et al. 2016), human mast cells (Rossi et al. 2016), and bovine ovarian cells (Dow et al. 2002). For example, a recent study has indicated that in cow preovulatory follicles, PLAU is only expressed in cumulus cells of immature and in vitro-matured cumulus-oocyte complexes (COCs), while PLAUR is expressed in both cumulus cells and immature and in vitro-matured oocytes (Garcia et al. 2016). Another study found that PLAU and PLAUR are expressed in GCs and residual ovarian preparations in a bovine follicular stage-dependent manner, implying that PLAU may be essential for overall growth of the developing follicles (Li et al. 1997). Remarkably, many findings describing the interaction between PLAU and PLAUR have provided new insights into the molecular mechanisms of supporting endothelial cell proliferation (Breuss \& Uhrin 2012), and inducing axonal regeneration (Merino et al. 2017), which indicates that cellular PLAUR expression and regulation play a crucial role in localizing and promoting PLAU action. However, whether the interaction of PLAU and PLAUR stimulate follicular cell proliferation remains to be determined.

The effects of PLAU/PLAUR on cell proliferation have been linked to cellular signaling transduction pathways in some cell types. It has recently been shown that CAMP is essential for proliferation of cell types including Schwann cells (Bacallao \& Monje 2013) and human mesenchymal stem cells (Kleiveland et al. 2008). These findings also highlight the fact that protein kinase $A$ (PKA) as a crucial cAMP effector is activated by cAMP to regulate cell proliferation (Okunishi et al. 2011, Rueda et al. 2016, Walia et al. 2016) and development (Fujita et al. 2002). In the hamster ovary, the extracellular signalregulated kinases 1 and 2 (ERK1/2, also known as MAPK 3 and 1 [MAPK3/1]) may act as intrafollicular mediators to regulate GC proliferation via FSH or EGF (Yang \& Roy 2004). It has been reported that cAMP-stimulated ERK phosphorylation was required for cell proliferation and function in the cAMP-dependent events related to cell growth (Le Pechon-Vallee et al. 2000, Vuchak et al. 2009, Van Kolen et al. 2010). Although cAMP and ERK are thought to play a crucial role in cell proliferation, the precise molecular mechanism of the interaction between them and PLAU in follicular development has not been completely elucidated.

Current evidence thus reflects a potential connection between PLAU-induced cell growth and CAMP and ERK signaling in GC proliferation. In this study, we aimed to analyze the localization of PLAU and PLAUR in bovine GCs cultured in vitro, and identify the cell proliferation signaling pathway stimulated by PLAU/PLAUR, in order to clarify their exact contribution to bovine follicular development.

\section{Materials and methods}

\section{Chemicals and reagents}

Most reagents have been labeled. Other materials included a protein marker from Thermo Fisher, BSA from Sigma, and glyceraldehyde 3-phosphate dehydrogenase (GAPDH) from Abcam.

\section{Granulosa cell isolation}

All animal procedures were performed in accordance with the guidelines established by, and with the approval of, the Animal Welfare and Research Ethics Committee of the Inner Mongolia Agricultural University, China (approval ID: 20170829-1). Briefly, bovine ovaries were collected in sterile physiological saline from a local slaughterhouse, transported to the laboratory at room temperature within $2 \mathrm{~h}$ of being slaughtered and rinsed three times with sterile physiological saline at $37^{\circ} \mathrm{C}$. Granulosa cells were aspirated from small (2-6 $\mathrm{mm}$ in diameter) follicles, using a $10-\mathrm{mL}$ syringe with an 18-gauge needle. A pipette was used to blow repeatedly to separate the oocytes and other follicular cells, then an oocyte collection needle was used to remove the oocyte and the partial cumulus cells attached to it. Remaining cells were then centrifuged at $298 \boldsymbol{g}$ for $3 \mathrm{~min}$ and the cell pellet was washed with a large volume of DMEM/F-12 (Gibco) supplemented with $12 \%(\mathrm{v} / \mathrm{v})$ FBS (Gibco) and 1\% (w/v) penicillin-streptomycin (Gibco). Cells were then dispersed by pipetting and washed one additional time.

\section{Cell culture and treatment}

The cells were seeded at a concentration of $5 \times 10^{4}$ cells/ $\mathrm{mL}$ in six-well cell culture-treated plates in DMEM/F12 with $12 \%(\mathrm{v} / \mathrm{v}) \mathrm{FBS}$ and $1 \%(\mathrm{w} / \mathrm{v})$ penicillin-streptomycin without or with one of the following: (1) PLAU (ab167714; Abcam); (2) amiloride (Cayman); (3) mouse monoclonal PLAUR antibody (SC-376494; 1:100; Santa Cruz, Inc); (4) Mouse nomal IgG2a (SC-3878; Santa Cruz, Inc); (5) U0126 (U120; Sigma); or (6) Rp-cAMP (Apoptosis and Epigenetics Company) at the recommended concentrations was added to continue the culture for the required amount of time. Untreated cells served as a negative control. The cells were incubated under 
a humidified atmosphere containing $5 \% \mathrm{CO}_{2}$ at $37^{\circ} \mathrm{C}$. All experiments were repeated at least three times.

\section{Immunofluorescence staining}

Cells were fixed with $4 \%$ paraformaldehyde for $30 \mathrm{~min}$ at room temperature and washed three times in DPBS. Then, cells were permeabilized in 0.4\% (v/v) Triton x-100 (Coolaber) for 15-30 min. After washing with DPBS, samples were incubated for 1 $\mathrm{h}$ in a blocking solution containing $10 \mathrm{~mL} 0.1 \%(\mathrm{w} / \mathrm{v})$ Triton $\mathrm{X}-100$, DPBS, and normal donkey serum (Jackson Immuno Research Laboratories). Subsequently, these cells were washed with DPBS and incubated at $4{ }^{\circ} \mathrm{C}$ overnight with rabbit polyclonal PLAU antibodies (SC-153; 1:100; Santa Cruz, INC) or mouse monoclonal PLAUR antibody (SC-376494; 1:100; Santa Cruz, INC) or mouse nomal IgG2a (SC-3878; 1:25; Santa Cruz, Inc) and rabbit nomal IgG (ab37415; 1:500; Abcam). Secondary antibodies were donkey anti-Rabbit (1:800; Jackson Immuno Research Laboratories, Inc) and donkey anti-Mouse (1:800; Jackson Immuno Research Laboratories, Inc). The cells were then counterstained with 4',6-diamidino-2-phenylindole $(1 \mu \mathrm{g} / \mathrm{mL}$ in PBS) for $15 \mathrm{~min}$. Digital images were captured using Laser confocal imaging (Nikon). We confirmed the specificity of PLAU and PLAUR antibodies used in bovine cells (Supplementary Fig. 1, see section on supplementary materials given at the end of this article).

\section{Cell proliferation assay}

To identify the individual effects of PLAU, amiloride, PLAUR antibody, U0126, and Rp-CAMP on granulosa cell proliferation, the number of living cells of post-treatment samples were determined using a cell counter. Granulosa cells in six-well plates were stimulated with one of the following: (1) $0,0.5,1,10$, or $100 \mathrm{ng} / \mathrm{mL}$ of PLAU; (2) 0,1 , or $10 \mu \mathrm{g} / \mathrm{mL}$ of amiloride or $2 \mu \mathrm{L} / \mathrm{mL}$ DMSO for 24 or $48 \mathrm{~h}$; (3) $10 \mu \mathrm{g} / \mathrm{mL}$ of PLAUR antibody for 24 and 48 h (Mohanam et al. 1993); (4) $10 \mu \mathrm{g} / \mathrm{mL}$ of mouse nomal IgG2a for 24 and $48 \mathrm{~h}$; (5) 20 $\mu \mathrm{M}$ of U0126 (Liu et al. 2019); or (5) $200 \mu \mathrm{M}$ of Rp-cAMP (Sun et al. 2015). They were then gently washed once with $200 \mu \mathrm{L}$ of $1 \times$ DPBS and exposed to $100 \mu \mathrm{L}$ of Trypsin-EDTA at $37^{\circ} \mathrm{C}$ for $3-5 \mathrm{~min}$. Digested cells from plates were scraped, collected, and enumerated by ORFLO automatic cell counter (Orflo Technologies, USA).

\section{Western blotting}

Granulosa cells were stimulated with $0.5 \mathrm{ng} / \mathrm{mL}$ PLAU, 1 $\mu \mathrm{g} / \mathrm{mL}$ amiloride, $10 \mu \mathrm{g} / \mathrm{mL}$ of PLAUR antibody , $10 \mu \mathrm{g} / \mathrm{mL}$ of mouse nomal IgG2a, $20 \mu \mathrm{M} \cup 0126$, or $200 \mu \mathrm{M}$ Rp-cAMP for $5 \mathrm{~min}$ in DMEM/F12 with $12 \%(\mathrm{v} / \mathrm{v})$ FBS and $1 \%(\mathrm{w} / \mathrm{v})$ penicillin-streptomycin after serum-free starvation for $12 \mathrm{~h}$. Protein samples from granulosa cells were prepared using radio immunoprecipitation assay (RIPA) buffer containing $1 \%(\mathrm{v} / \mathrm{v})$ phenylmethylsulfonyl fluoride (Sigma) and 1\% (v/v) phosphatase inhibitor (Roche). After centrifuging the mixture, the protein concentration in the supernatant was determined by bicinchoninic acid (BCA) assay. Lysed samples were mixed with loading sample buffer (Sigma), then boiled for $5 \mathrm{~min}$ and centrifuged for $10 \mathrm{~min}$ at 13,200 $\mathrm{g}$. The same volume of protein $(20 \mu \mathrm{L})$ was separated by $12 \%(\mathrm{w} / \mathrm{v})$ SDS-PAGE and electrotransferred onto a nitrocellulose membrane (Pall). Membranes were blocked with Odyssey blocking buffer for $1 \mathrm{~h}$ at room temperature and then incubated with rabbit antiERK1/2 (9102; Cell Signaling Technology) and mouse antiphospho-ERK1/2 (9106; Cell Signaling Technology) at $4^{\circ} \mathrm{C}$ overnight respectively followed by incubation with secondary antibodies, donkey anti-rabbit (ab175772; 1:10,000; Abcam), and donkey anti-mouse (ab175782; 1:10,000; Abcam) for $1 \mathrm{~h}$ at room temperature. Proteins were detected and imaged with the ChemiDoc ${ }^{\text {TM }}$ XRS+ system (Odyssey; LI-COR Biosciences). Experiments were repeated three times.

\section{ELISA}

After pre-cultured for $24 \mathrm{~h}$, granulosa cells were treated with DMEM/F12 supplemented with $1 \%(\mathrm{w} / \mathrm{v})$ penicillinstreptomycin for $12 \mathrm{~h}$ of serum-free starvation, then simulated with (1) 0 or $0.5 \mathrm{ng} / \mathrm{mL}$ PLAU; (2) $1 \mu \mathrm{g} / \mathrm{mL}$ amiloride; (3) PLAU plus amiloride; (4) 0 or $0.5 \mathrm{ng} / \mathrm{mL}$ PLAU; (5) $10 \mu \mathrm{g} / \mathrm{mL}$ of mouse nomal IgG2a; (6) $10 \mu \mathrm{g} / \mathrm{mL}$ PLAUR antibody; or (7) PLAU plus PLAUR antibody. An aliquot of each sample was assayed for the cAMP level using a cAMP ELISA kit (581001; Cayman) according to the manufacturer's protocol. After simulating cells containing different types of factor for $5 \mathrm{~min}$, the cells were incubated in $1 \mathrm{~mL}$ of $0.1 \mathrm{M} \mathrm{HCl}$ for $20 \mathrm{~min}$ at room temperature. Subsequently, the plates were covered for $18 \mathrm{~h}$ at $4^{\circ} \mathrm{C}$ with the corresponding reagents and washed. After adding Ellman's reagent and tracer in turn, the plates were incubated for 90-120 min at room temperature in the dark. Each experiment was carried out in triplicate.

\section{Statistical analysis}

Each experiment was repeated at least three times. Data represent the mean \pm S.E.M. of the values obtained. Statistical analyses using GraphPad Prism 5.0 (GraphPad Software) included one-way ANOVA followed by Tukey's test for comparing among all groups and Student' $s$ t-test for comparing between two groups. Significance was inferred when $P<0.05$.

\section{Results}

\section{Expression of PLAU and PLAUR in bovine granulosa cells}

To investigate the existence of a functional interaction between PLAU and PLAUR in GCs, we first evaluated the localization of PLAU and PLAUR proteins in bovine GCs cultured in vitro by immunocytochemistry. As shown in Fig. 1A, our results revealed the presence of both proteins in GCs suggesting that PLAU and PLAUR may play a role in the process of bovine granulosa cell development. No signal was detected in the isotype antibody negative control (Fig. 1B). 

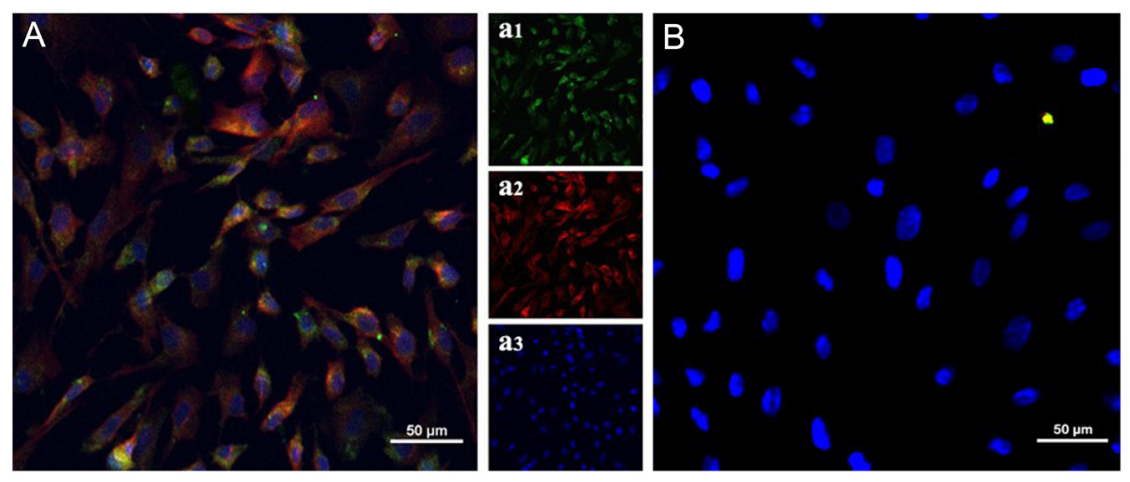

Figure 1 Expression of PLAU and PLAUR in bovine granulosa cells. Immunocytochemistry with anti-PLAU antibody and anti-PLAUR antibody evaluating PLAU and PLAUR expression in bovine granulosa cells. (A) Image of PLAU (red) and PLAUR (green) staining in granulosa cells. Scale bar, $50 \mu \mathrm{m}$. Staining for PLAUR (a1) and PLAU (a2) were seen between granulosa cells. (a3) Nuclei were counterstained with DAPI (blue). (B) In the control case, when the antibodies are nonspecific IgG of mouse and rabbit, no binding to the cells is seen in the fluorescence image.

\section{PLAU promotes bovine granulosa cell proliferation by binding to PLAUR}

GCs were cultured in the absence and presence of 0.5, 1,10 , or $100 \mathrm{ng} / \mathrm{mL}$ PLAU for 24 or $48 \mathrm{~h}$ to evaluate the possible effects of PLAU dose on cell proliferation using an automated counter. As shown in Fig. 2A, GCs were more numerous in all PLAU-treated groups in comparison with those in the control and reached a significantly higher level at $0.5 \mathrm{ng} / \mathrm{mL}$ PLAU when cultured for 24 or $48 \mathrm{~h}(P<0.001)$. In addition, GC proliferation was assessed after treatment with amiloride, a specific PLAU inhibitor, revealing that amiloride

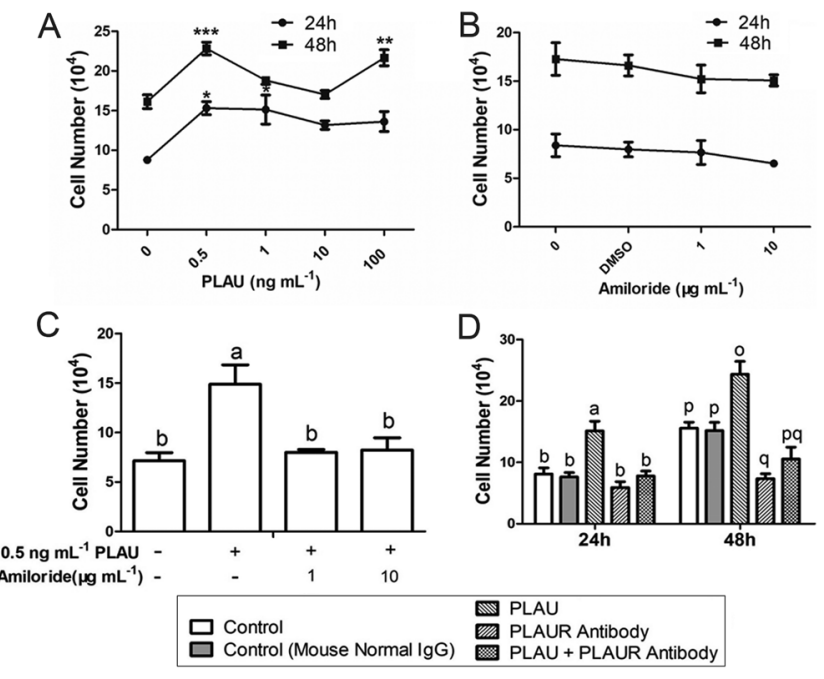

Figure 2 Effects of PLAU and PLAUR on the proliferation of bovine granulosa cells. Bovine granulosa cells were treated with different concentrations of (A) PLAU and (B) amiloride for 24 and $48 \mathrm{~h}$. Amiloride was dissolved in $0.2 \%$ dimethyl sulfoxide (DMSO). (C) Effects of PLAU $(0.5 \mathrm{ng} / \mathrm{mL})$, and the combinations of PLAU (0.5 ng/ $\mathrm{mL}$ ) and amiloride (1 or $10 \mu \mathrm{g} / \mathrm{mL}$ ) on granulosa cell proliferation after $24 \mathrm{~h}$ of culture. (D) Granulosa cells were treated with PLAU (0.5 $\mathrm{ng} / \mathrm{mL})$, PLAUR antibody $(10 \mu \mathrm{g} / \mathrm{mL})$, and their combinations for 24 and $48 \mathrm{~h}$. Mouse nomal lgG2a was added in the control case. A cell counting assay was then performed to analyze proliferation of granulosa cells. Data are means \pm S.E.M. of three independent experiments. ${ }^{*} P<0.05,{ }^{* *} P<0.01$, and ${ }^{* * *} P<0.001$ vs control. Letters with different superscripts are significantly different at $P<$ 0.05 , compared with control. treatment at different concentrations of 1 and $10 \mu \mathrm{g} /$ $\mathrm{mL}$ did not affect GC proliferation when compared to the control group whether cultured for 24 or $48 \mathrm{~h}$ in vitro (Fig. 2B). To further investigate the effect of PLAU on GC proliferation, GCs were randomly divided into four groups and treated with PLAU $(0.5 \mathrm{ng} / \mathrm{mL})$ and the combinations of PLAU $(0.5 \mathrm{ng} / \mathrm{mL}$ and amiloride (1 or 10 $\mu \mathrm{g} / \mathrm{mL}$ ) and cultured for $24 \mathrm{~h}$ in vitro. Consistent with the findings noted above, the results showed that PLAU significantly elevated GC proliferation, which could be downregulated by amiloride supplement together with PLAU $(P<0.05)$ (Fig. 2C). In view of previous reports that PLAU exerts a proliferative effect through binding to PLAUR (Merino et al. 2017, Nguyen et al. 1999), our next experiment was designed to test whether PLAU promotes GC proliferation by binding to PLAUR. Bovine GCs were treated with PLAU $(0.5 \mathrm{ng} / \mathrm{mL})$, mouse nomal IgG2a (10 $\mu \mathrm{g} / \mathrm{mL})$, PLAUR antibody $(10 \mu \mathrm{g} / \mathrm{mL})$ or co-treated with PLAU $(0.5 \mathrm{ng} / \mathrm{mL})$ and PLAUR antibody $(10 \mu \mathrm{g} / \mathrm{mL})$ and cultured for 24 and $48 \mathrm{~h}$. The results showed there existed a sharp decline in GC numbers after co-treated with PLAU and PLAUR antibody when compared with that treated with PLAU alone $(P<0.05)$ and PLAUR antibody treatment alone resulted in the invariable GC number after cultured for 24 and $48 \mathrm{~h}$ (Fig. 2D) suggesting that the interplay between PLAU and PLAUR was required for PLAU-induced GC proliferation and PLAUR may have an essential physiological effects on GC proliferation.

\section{PLAU binding to PLAUR promotes granulosa cell proliferation via the MAPK/ERK1/2 pathway}

It has been reported that in breast cells, PLAU could initiate a PLAUR-dependent signaling cascade in which ERK serves as an essential downstream effector (Nguyen et al. 1999). To test whether the MAPK/ERK1/2 pathway may associate with PLAU-induced GC proliferation by its binding to PLAUR, we treated GCs with PLAU $(0.5 \mathrm{ng} / \mathrm{mL})$ for $0,2,5,10$, and 20 min respectively and performed Western blotting using antibodies against phosphorylated and unphosphorylated-ERK1/2. As shown in Fig. 3A, the remarkably increased ERK activity was observed in GCs cultured in vitro with PLAU for 5 min compared to that in the control $(P<0.05)$. In view of this observation, we 
further tested the effect of PLAU on ERK phosphorylation by co-treatment with amiloride, a specific PLAU inhibitor. GCs were divided into four groups and treated with PLAU $(0.5 \mathrm{ng} / \mathrm{mL})$, amiloride $(1 \mu \mathrm{g} / \mathrm{mL})$, and a combination of PLAU $(0.5 \mathrm{ng} / \mathrm{mL})$ and amiloride $(1 \mu \mathrm{g} / \mathrm{mL})$ for 5 min. As shown in Fig. 3B, PLAU increased the ratio of phosphorylated to unphosphorylated ERK1/2, which could be attenuated by amiloride. In addition, GCs were treated with PLAU $(0.5 \mathrm{ng} / \mathrm{mL})$, mouse nomal IgG2a (10 $\left.\mu \mathrm{g} / \mathrm{mL}^{1}\right)$, PLAUR antibody $(10 \mu \mathrm{g} / \mathrm{mL})$, and a combination of PLAU $(0.5 \mathrm{ng} / \mathrm{mL})$ and PLAUR antibody $(10 \mu \mathrm{g} / \mathrm{mL})$. The results showed that PLAU-induced ERK activity could be significantly inhibited by PLAUR antibody co-treatment (Fig. 3C). Finally, we tested the possible effects of MAPKERK signaling on GC proliferation. The results indicated that U0126 suppressed PLAU/PLAUR-induced ERK1/2 phosphorylation and GC proliferation (Fig. 3D and E) suggesting the involvement of the ERK1/2 pathway in PLAU/PLAUR-induced effects on bovine GCs.

\section{PLAU-induced granulosa cell proliferation via the ERK1/2 pathway is dependent on CAMP signaling}

The above data revealed that PLAU binding to PLAUR enhanced GC proliferation by activating the ERK1/2 pathway. Previous studies reported that cAMP stimulates the proliferation of epithelial cells of polycystic kidney through PKA-induced activation of the ERK pathway (Spirli et al. 2010), which indicates that cAMP is an upstream target of the ERK $1 / 2$ pathway, in relation to cell proliferation. To determine whether PLAU-induced GC proliferation via the ERK $1 / 2$ pathway is dependent on cAMP signaling, we first treated GCs with PLAU $(0.5 \mathrm{ng} / \mathrm{mL})$ for $0,2,5$ and $10 \mathrm{~min}$ respectively and performed ELISA to detect bovine GC cAMP level. The results showed that PLAU treatment remarkedly elevated the cAMP level in GCs after cultured for 2, 5, and 10 min when compared to that in the control $(P<0.05)$ (Fig. 4A). Secondly, we investigated the possible effects of the interplay between PLAU and PLAUR on bovine GC cAMP levels. The results showed that PLAU-induced intracellular CAMP level was remarkably attenuated by amiloride (Fig. 4B) and by PLAUR antibody (Fig. 4C, manifesting that PLAU may mediate CAMP signaling by binding to PLAUR. To test our hypothesis that PLAU and PLAUR could activate the intracellular CAMP signal then induce GC proliferation via ERK1/2, we adopted Rp-cAMP as the specific PKA inhibitor in view of its competitive antagonism of cAMP (Tong et al. 2017). In the present study, bovine GCs were divided into four
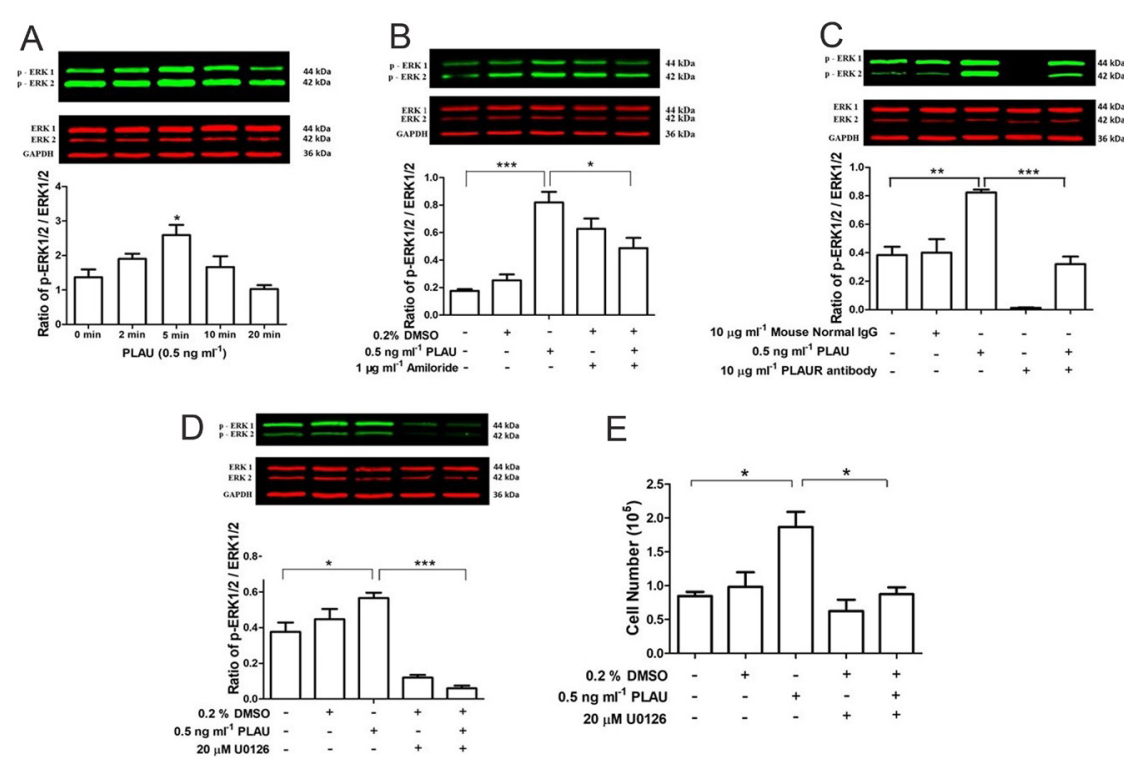

E
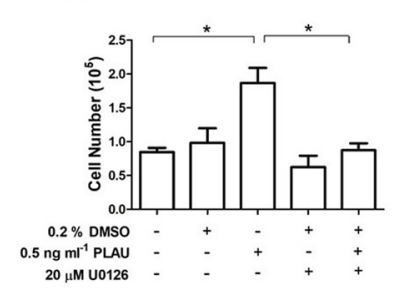

Figure 3 Effect of ERK1/2 on PLAU-induced granulosa cell proliferation. (A) Time course of ERK1/2 phosphorylation induced by PLAU in granulosa cells. We added PLAU $(0.5 \mathrm{ng} / \mathrm{mL})$ to the medium for 0-20 min as indicated. (B) Effect of the PLAU inhibitor amiloride on PLAU-induced phosphorylation of ERK1/2. Granulosa cells were pretreated for $5 \mathrm{~min}$ in PLAU $(0.5 \mathrm{ng} / \mathrm{mL})$, amiloride $(1 \mu \mathrm{g} / \mathrm{mL})$ or PLAU plus amiloride. Amiloride was dissolved in $0.2 \%$ dimethyl sulfoxide (DMSO). (C) Effect of PLAU receptor antibody on PLAU-induced phosphorylation of ERK1/2. Granulosa cells were stimulated for $5 \mathrm{~min}$ in mouse nomal IgG2a $(10 \mu \mathrm{g} / \mathrm{mL})$, PLAU $(0.5 \mathrm{ng} / \mathrm{mL})$, PLAUR antibody $(10 \mu \mathrm{g} / \mathrm{mL})$, and PLAU plus PLAUR antibody. (D) Effect of the ERK inhibitor U0126 on PLAU-induced phosphorylation of ERK1/2. Granulosa cells were pretreated with PLAU $(0.5 \mathrm{ng} / \mathrm{mL}), \mathrm{U} 0126(20 \mu \mathrm{M})$, or PLAU plus U0126 for 5 min. U0126 was dissolved in $0.2 \%$ dimethyl sulfoxide (DMSO). Protein levels of phosphorylated and nonphosphorylated ERK1/2 (44 and $42 \mathrm{kDa}$ ) in cell lysates were detected by Western blot analysis. (E) Effect of the ERK1/2 inhibitor U0126 on PLAU-induced granulosa cell proliferation. Granulosa cells were incubated with PLAU $(0.5 \mathrm{ng} / \mathrm{mL}), \mathrm{U} 0126(20 \mu \mathrm{M})$, and their combinations for $24 \mathrm{~h}$, and proliferation was evaluated by cell counting. Data are means \pm S.E.M. of three independent experiments. ${ }^{*} P<$ $0.05, * * P<0.01, * * * P<0.001$. 

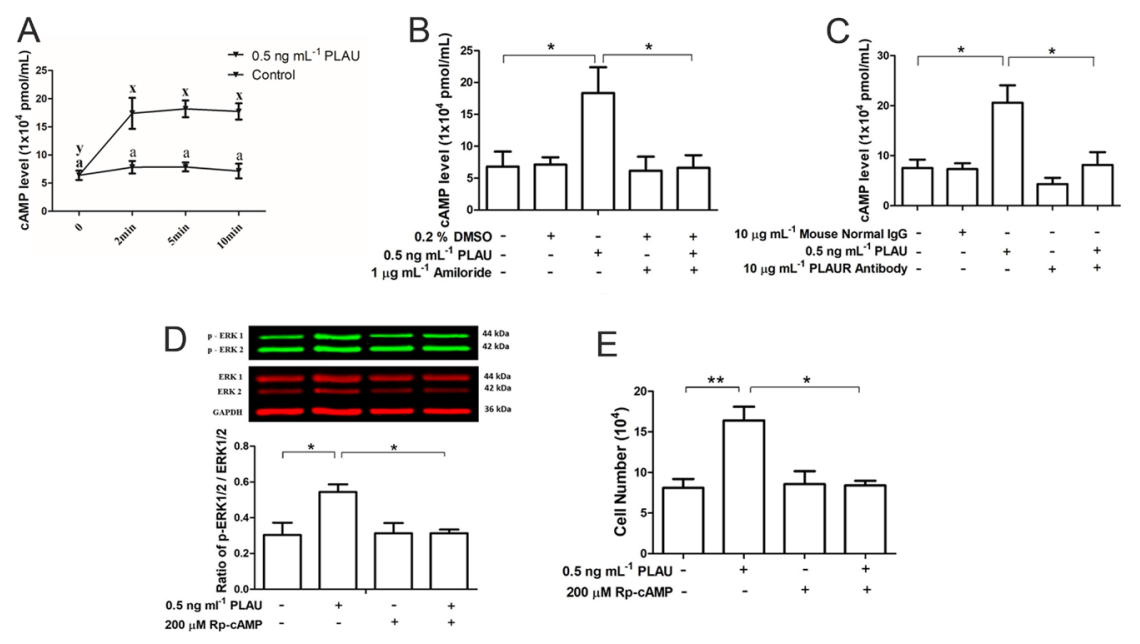

Figure 4 Influence of cAMP on PLAU-induced granulosa cell proliferation via ERK1/2. (A, B and C) Stimulation of CAMP production via PLAU binding to PLAUR was detected by CAMP ELISA assays. (A) Time course of cAMP production induced by PLAU in granulosa cells. We added PLAU $(0.5 \mathrm{ng} / \mathrm{mL})$ to the medium for 0-10 min as indicated. (B) Granulosa cells were stimulated with PLAU (0.5 ng/mL), amiloride $(1 \mu \mathrm{g} / \mathrm{mL})$, or PLAU plus amiloride for $5 \mathrm{~min}$. Amiloride was dissolved in $0.2 \%$ dimethyl sulfoxide (DMSO). (C) Granulosa cells were stimulated with mouse nomal IgG2a $(10 \mu \mathrm{g} / \mathrm{mL})$,PLAU $(0.5$ $\mathrm{ng} / \mathrm{mL})$, PLAUR antibody $(10 \mu \mathrm{g} / \mathrm{mL})$, and PLAU plus PLAUR antibody for $5 \mathrm{~min}$. (D) Effect of CAMP on PLAU-induced ERK1/2. Granulosa cells were incubated with PLAU $(0.5 \mathrm{ng} / \mathrm{mL})$, Rp-cAMP $(200 \mu \mathrm{M})$, or their combinations for $5 \mathrm{~min}$, and protein levels of phosphorylated and non-phosphorylated ERK1/2 (44 and $42 \mathrm{kDa}$ ) in cell lysates were detected by Western blot analysis. (E) Effect of CAMP on PLAU-induced granulosa cell proliferation. Granulosa cells were treated with PLAU $(0.5 \mathrm{ng} / \mathrm{mL})$, Rp-cAMP $(200 \mu \mathrm{M})$, or their combinations for $24 \mathrm{~h}$ and cell proliferation was evaluated by cell counting. Data are means \pm S.E.M. of three independent experiments. $* P<0.05,{ }^{* *} P<0.01$. groups and treated with PLAU $(0.5 \mathrm{ng} / \mathrm{mL}), \mathrm{Rp}-\mathrm{cAMP}$ $(200 \mu \mathrm{M})$, or a combination of PLAU $(0.5 \mathrm{ng} / \mathrm{mL})$ and $\operatorname{Rp}$-CAMP $(200 \mu \mathrm{M})$ for 5 min or $24 \mathrm{~h}$ respectively and performed Western blotting or cell proliferation assay. The results showed that PLAU-induced elevation in the ratio of phosphorylated to unphosphorylated ERK1/2, and GC proliferation, could be attenuated by Rp-cAMP exposure (Fig. 4D and E) indicating that PLAU-mediated GC proliferation via the ERK1/2 pathway is dependent on cAMP signaling.

\section{Discussion}

Although previous studies have described PLAU and PLAUR mRNAs or proteins in porcine (Hwang et al. 2018) and bovine (Garcia et al. 2016) antral follicles, it remained unknown whether PLAU and PLAUR contribute to early follicular development. Here, our results demonstrated that PLAU and PLAUR localized in bovine GCs from developing follicles, where they may have a vital role in GC proliferation via induction of cAMP accumulation, enable MAPK/ ERK1/2 activation. This provides mechanistic insights into PLAU and PLAUR-induced bovine GC proliferation supporting their contribution to follicular growth in the developing ovary.

GCs are the major somatic cells of the follicular wall having a crucial role in follicular development. In the present study, bovine GCs were obtained from antral follicles (2-6 $\mathrm{mm}$ in diameter) and cultured in vitro. Our results showed that both PLAU and PLAUR proteins localized in GCs cultured in vitro. This was consistent with the previous report by Li et al. (1997) who showed PLAU and PLAUR protein expression in rat GCs in vivo suggesting that PLAU and PLAUR may be involved in GC function during follicular development. A similar effect was also observed only in cumulus cells where PLAU and PLAUR were expressed (Garcia et al. 2016). It has been reported that PLAU-induced effects are dependent on its binding to PLAUR (Blasi 1999, Ossowski \& Aguirre-Ghiso 2000). Thus, our findings suggested that PLAU may be involved in triggering the autocrine pathways through binding to its receptor in GCs, producing a series of transduction signals, and exerting a physiological function during follicular development.

To further confirm the potential regulation of PLAU and PLAUR in follicular development, we examined the effects of PLAU and PLAUR interaction on the proliferation of bovine GCs cultured in vitro. In a previous report, bovine follicles were classified into small $(<7 \mathrm{~mm})$, intermediate $(7-10 \mathrm{~mm})$ and large $(>10$ $\mathrm{mm}$ ) diameter follicles, and small follicular GCs were more proliferative when compared to large follicular GCs (Bartholomeusz et al. 1988). Based on this, we obtained bovine GCs from antral follicles $2-6 \mathrm{~mm}$ in diameter and evaluated the effects of PLAU on GC proliferation. Our results showed that PLAU significantly promoted GC proliferation, which could be downregulated by the addition of amiloride. This indicated that PLAU may play 
a role in promoting small follicular GC proliferation. It is well-established that amiloride can prevent PLAUinduced effects specifically as a specific competitive inhibitor of PLAU (Vassalli \& Belin 1987, Hu et al. 2019). It has been reported that PLAU depletion largely impaired murine cumulus expansion and subsequent oocyte maturation via its specific inhibitor, amiloride (Lu et al. 2013). Previous studies have shown that the interaction between PLAU and its membrane receptor (PLAUR) can promote proliferation of various types of cells, including muscle cells (Novak et al. 2011), human myeloid cells (Nusrat \& Chapman 1991), and synovial cells (Del Rosso et al. 2005). Meanwhile, PLAU/PLAUR downregulation suppresses angiogenesis in endothelial cells (Raghu et al. 2010). We observed an analogous effect namely that PLAU-induced bovine GC proliferation was prevented by PLAUR antibody. It was reported that anti-PLAUR MAB could block PLAUsimulated effects effectively at $10 \mu \mathrm{g} / \mathrm{mL}$ (Mohanam et al. 1993). Our results showed that PLAU-induced GC proliferation is blocked by PLAUR antibody at the same concentration $(10 \mu \mathrm{g} / \mathrm{mL})$, and GC proliferation could be remarkably prevented within $48 \mathrm{~h}$ after PLAUR antibody exposure, suggesting that PLAUR-dependent PLAU activity could play a physiological role in early follicular development by promoting bovine GC proliferation.

The ERK signal transduction pathway plays an important role in ovarian follicular development (Evans \& Martin 2000, Ryan et al. 2007). ERK1/2 phosphorylation was comparatively decreased in GCs from polycystic ovary syndrome (Lan et al. 2015). In GCs, the MAPKERK pathway has been demonstrated to be involved in cell proliferation. The ERK $1 / 2$ pathway has been implicated in hepatocyte growth factor-induced cell proliferation in human GCs (Taniguchi et al. 2004) and also associated with proliferation-inducing effects of

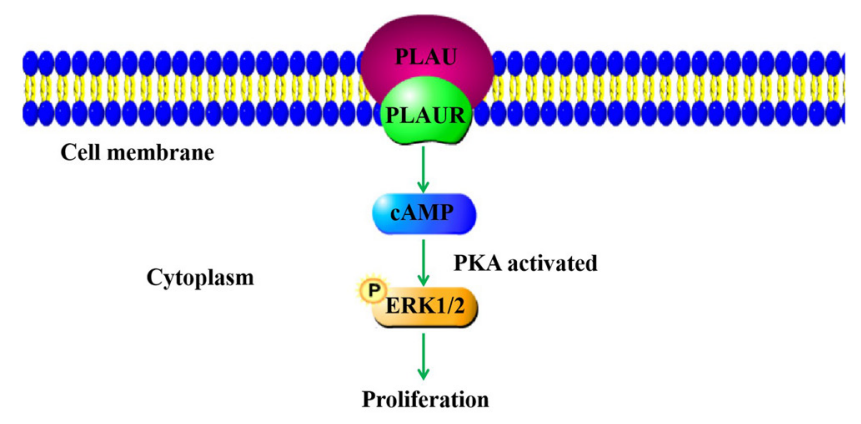

Granulosa cell

Figure 5 Plasminogen activator, urokinase (PLAU) and its receptor (PLAUR)-mediated granulosa cells proliferation pathways. A schematic model illustrating the function of PLAU to mediate proliferation of bovine granulosa cells. Through binding to PLAUR, PLAU elevates cAMP level, resulting in activation of the ERK1/2 signaling pathway, and thereby promoting granulosa cell proliferation.
pDEFB103A on porcine GCs (Liu et al. 2019). These findings indicate the function of ERK1/2 signaling in ovarian GC proliferation. Our demonstration that the binding of PLAU to PLAUR enhanced small folliclederived granulosa cell proliferation via the ERK1/2 pathway during follicular development suggests novel factors in the regulation of ovarian function via this key pathway. The MAPK pathway can be activated by PLAU through binding to PLAUR, promoting proliferation of breast cells (Ma et al. 2001, Gandhari et al. 2006). Our result that the ERK1/2 pathway associated with PLAUinduced bovine GC proliferation is consistent with the results of these studies on breast cells.

The cAMP-PKA signaling cascade is associated with MAPK-ERK-regulated cell proliferation (Takahashi et al. 2004). PKA is a multi-target kinase activated by the ubiquitous second messenger, 3',5'-cyclic adenosine monophosphate. Accumulating evidence has suggested that CAMP regulates proliferation of various cells through ERK activation depending on the PKA cascade (Gaudio et al. 2006, Spirli et al. 2010). In HEK293 cells, ERKs completely suppressed by PKA inhibitor (Li et al. 2016) could be activated after treatment for 20 min with both forskolin and IBMX, which also induced additional elevation of cAMP levels. Consistent with the above findings, we showed that ERK1/2 activation and GC proliferation induced by PLAU could be attenuated by Rp-cAMP. It has been reported that Rp-cAMP, a specific PKA inhibitor, could effectively block salusin $\beta$-induced ERK phosphorylation and vascular smooth muscle proliferation at $200 \mu \mathrm{M}$ (Sun et al. 2015), the same concentration as that used in our experiment. A previous study observed a significant reduction in cAMP-induced effects on PLAU-deficient primary murine tracheal epithelial cells (Chen et al. 2014), which is consistent with our finding that PLAU can enhance the intercellular cAMP level in bovine GCs, dependent on PLAUR signaling. Taken together, our results suggested that PLAU-induced GC proliferation via the ERK1/2 pathway is dependent on CAMP signaling.

How cAMP signal is involved in PLAU-induced GC proliferation needs to be further investigated. Previous studies reported that murine embryonic fibroblasts proliferated in response to EGF only when these cells expressed PLAUR (Jo et al. 2007), and EGF mitogenic activity could be blocked by PLAU gene silencing or with antibodies that block PLAU binding to PLAUR (Zhou et al. 2018), suggesting a potential role of EGF/ EGFR signaling in PLAU-induced cell proliferation. Meanwhile, it has been reported that EGF increased CAMP production and amylase release in pancreatic acini (Stryjek-Kaminska et al. 1995) and the EGF-activation of EGFR induced CAMP response element-binding protein (CREB) phosphorylation in cumulus cells (Zhang et al. 2019), indicating a special mechanism of EGF/EGFRdependent CAMP production. Based on the above, we 
speculate that EGF-EGFR signaling may be the potential pathway involved in PLAU-induced intracellular CAMP production and GC proliferation.

In summary, this study reveals for the first time the molecular mechanism controlling PLAU/PLAURinduced bovine GC proliferation (Fig. 5). Our results support the previous hypothesis that PLAU is important in follicular wall remodeling at the early stages of follicular development ( $\mathrm{Li}$ et al. 1997). Future work should aim to acquire relevant in vivo evidence, which will help in understanding the mechanisms underlying early follicular development.

\section{Supplementary materials}

This is linked to the online version of the paper at https://doi. org/10.1530/REP-20-0165.

\section{Declaration of interest}

The authors declare that there is no conflict of interest that could be perceived as prejudicing the impartiality of the research reported.

\section{Funding}

This work was supported by two grants from the National Natural Science Foundation of China (nos. 31760717 and 31360283), one from the Inner Mongolia Natural Science Foundation (no. 2012MS0411).

\section{Author contribution statement}

Y F Z was involved in data curation, conceptualization, methodology, writing the original draft, and software analysis. B Y Y contributed to the conceptualization, methodology, writing the original draft, writing, reviewing and editing the manuscript. $X Y L$ was involved in data curation and methodology. J $\mathrm{TH}$ was involved in data curation and methodology. $Y Y Y$ and $E N$ were involved in data curation. $B X Y, Y B$, and $Y H$ Q contributed to the formal analysis. H J L was involved in conceptualization, funding acquisition, project administration, resources, writing, reviewing and editing the manuscript.

\section{Acknowledgements}

The authors thank Gerile Subudeng and Xiumei Wang for discussion and members of the Li lab for commenting on an early draft of the manuscript. The authors would like to thank Editage [www.editage.cn] for English language editing.

\section{References}

Bacallao K \& Monje PV 2013 Opposing roles of PKA and EPAC in the CAMPdependent regulation of Schwann cell proliferation and differentiation [corrected]. PLOS ONE 8 e82354. (https://doi.org/10.1371/journal. pone.0082354)
Bartholomeusz RK, Bertoncello I \& Chamley WA 1988 A correlation between ovarian follicular maturity and anchorage-independent growth of bovine granulosa cells. International Journal of Cell Cloning 6 106-115. (https://doi.org/10.1002/stem.5530060204)

Blasi F 1999 Proteolysis, cell adhesion, chemotaxis, and invasiveness are regulated by the u-PA-u-PAR-PAI-1 system. Thrombosis and Haemostasis 82 298-304. (https://doi.org/10.1055/s-0037-1615846)

Breuss JM \& Uhrin P 2012 VEGF-initiated angiogenesis and the uPA/ uPAR system. Cell Adhesion and Migration 6 535-615. (https://doi. org/10.4161/cam.22243)

Chen Z, Zhao R, Zhao M, Liang X, Bhattarai D, Dhiman R, Shetty S, Idell S \& Ji HL 2014 Regulation of epithelial sodium channels in urokinase plasminogen activator deficiency. American Journal of Physiology: Lung Cellular and Molecular Physiology 307 L609-L617. (https://doi. org/10.1152/ajplung.00126.2014)

Colgin DC \& Murdoch WJ 1997 Evidence for a role of the ovarian surface epithelium in the ovulatory mechanism of the sheep: secretion of urokinase-type plasminogen activator. Animal Reproduction Science 47 197-204. (https://doi.org/10.1016/s0378-4320(97)00011-0)

Del Rosso A, Cinelli M, Guiducci S, Pignone A, Fibbi G, Margheri F, Gabrielli A, Giacomelli R, Coppini A, Del Rosso M, et al. 2005 Deflazacort modulates the fibrinolytic pattern and reduces uPAdependent chemioinvasion and proliferation in rheumatoid arthritis synoviocytes. Rheumatology 44 1255-1262. (https://doi.org/10.1093/ rheumatology/kei006)

Dow MP, Bakke LJ, Cassar CA, Peters MW, Pursley JR \& Smith GW 2002 Gonadotropin surge-induced up-regulation of the plasminogen activators (tissue plasminogen activator and urokinase plasminogen activator) and the urokinase plasminogen activator receptor within bovine periovulatory follicular and luteal tissue. Biology of Reproduction 66 1413-1421. (https://doi.org/10.1095/biolreprod66.5.1413)

Evans AC \& Martin F 2000 Kinase pathways in dominant and subordinate ovarian follicles during the first wave of follicular development in sheep. Animal Reproduction Science 64 221-231. (https://doi.org/10.1016/ s0378-4320(00)00210-4)

Fujita T, Meguro T, Fukuyama R, Nakamuta H \& Koida M 2002 New signaling pathway for parathyroid hormone and cyclic AMP action on extracellular-regulated kinase and cell proliferation in bone cells. Checkpoint of modulation by cyclic AMP. Journal of Biological Chemistry 277 22191-22200. (https://doi.org/10.1074/jbc.M110364200)

Gandhari M, Arens N, Majety M, Dorn-Beineke A \& Hildenbrand R 2006 Urokinase-type plasminogen activator induces proliferation in breast cancer cells. International Journal of Oncology 28 1463-1470. (https:// doi.org/10.3892/ijo.28.6.1463)

Garcia DC, Miceli DC, Rizo G, Garcia EV, Valdecantos PA \& RoldanOlarte M 2016 Expression and localization of urokinase-type plasminogen activator receptor in bovine cumulus-oocyte complexes. Zygote 24 230-235. (https://doi.org/10.1017/S0967199415000076)

Gaudio E, Barbaro B, Alvaro D, Glaser S, Francis H, Ueno Y, Meininger CJ, Franchitto A, Onori P, Marzioni M, et al. 2006 Vascular endothelial growth factor stimulates rat cholangiocyte proliferation via an autocrine mechanism. Gastroenterology 130 1270-1282. (https://doi. org/10.1053/j.gastro.2005.12.034)

Hu Y, Barron AO, Gindina S, Kumar S, Chintala S, Nayyar A \& Danias J 2019 Investigations on the role of the fibrinolytic pathway on outflow facility regulation. Investigative Ophthalmology and Visual Science 60 1571-1580. (https://doi.org/10.1167/iovs.18-25698)

Hwang SU, Kim KJ, Kim E, Yoon JD, Park KM, Jin M, Han Y, Kim M, Lee G \& Hyun SH 2018 Lysophosphatidic acid increases in vitro maturation efficiency via UPA-UPAR signaling pathway in cumulus cells. Theriogenology 113 197-207. (https://doi.org/10.1016/j. theriogenology.2018.02.020)

Jo M, Thomas KS, Takimoto S, Gaultier A, Hsieh EH, Lester RD \& Gonias SL 2007 Urokinase receptor primes cells to proliferate in response to epidermal growth factor. Oncogene 26 2585-2594. (https:// doi.org/10.1038/sj.onc.1210066)

Kleiveland CR, Kassem M \& Lea T 2008 Human mesenchymal stem cell proliferation is regulated by PGE2 through differential activation of CAMP-dependent protein kinase isoforms. Experimental Cell Research 314 1831-1838. (https://doi.org/10.1016/j.yexcr.2008.02.004)

Lan CW, Chen MJ, Tai KY, Yu DC, Yang YC, Jan PS, Yang YS, Chen HF \& Ho HN 2015 Functional microarray analysis of differentially expressed genes in granulosa cells from women with polycystic ovary syndrome 
related to MAPK/ERK signaling. Scientific Reports 5 14994. (https://doi. org/10.1038/srep14994)

Le Pechon-Vallee C, Magalon K, Rasolonjanahary R, Enjalbert A \& Gerard C 2000 Vasoactive intestinal polypeptide and pituitary adenylate cyclase-activating polypeptides stimulate mitogen-activated protein kinase in the pituitary cell line GH4C1 by a 3',5'-cyclic adenosine monophosphate pathway. Neuroendocrinology 72 46-56. (https://doi. org/10.1159/000054570)

Li M, Karakji EG, Xing R, Fryer JN, Carnegie JA, Rabbani SA \& Tsang BK 1997 Expression of urokinase-type plasminogen activator and its receptor during ovarian follicular development. Endocrinology 138 2790-2799. (https://doi.org/10.1210/endo.138.7.5221)

Li Y, Dillon TJ, Takahashi M, Earley KT \& Stork PJ 2016 Protein kinase A-independent Ras protein activation cooperates with Rap1 protein to mediate activation of the extracellular signal-regulated kinases (ERK) by cAMP. Journal of Biological Chemistry 291 21584-21595. (https://doi. org/10.1074/jbc.M116.730978)

Liu DF \& Rabbani SA 1995 Induction of urinary plasminogen activator by retinoic acid results in increased invasiveness of human prostate cancer cells PC-3. Prostate 27 269-276. (https://doi.org/10.1002/ pros.2990270506)

Liu C, Pan B, Yang L, Wang B \& Li J 2019 Beta defensin 3 enhances ovarian granulosa cell proliferation and migration via ERK1/2 pathway in vitrodagger. Biology of Reproduction 100 1057-1065. (https://doi. org/10.1093/biolre/ioy246)

Lu CH, Lee RK, Hwu YM, Lin MH, Yeh LY, Chen YJ, Lin SP \& Li SH 2013 Involvement of the serine protease inhibitor, SERPINE2, and the urokinase plasminogen activator in cumulus expansion and oocyte maturation. PLOS ONE 8 e74602. (https://doi.org/10.1371/journal.pone.0074602)

Ma Z, Webb DJ, Jo M \& Gonias SL 2001 Endogenously produced urokinasetype plasminogen activator is a major determinant of the basal level of activated ERK/MAP kinase and prevents apoptosis in MDA-MB-231 breast cancer cells. Journal of Cell Science 114 3387-3396.

Merino P, Diaz A, Jeanneret V, Wu F, Torre E, Cheng L \& Yepes M 2017 Urokinase-type plasminogen activator (uPA) binding to the uPA receptor (UPAR) promotes axonal regeneration in the central nervous system. Journal of Biological Chemistry 292 2741-2753. (https://doi. org/10.1074/jbc.M116.761650)

Mohanam S, Sawaya R, Mccutcheon I, Ali-Osman F, Boyd D \& Rao JS 1993 Modulation of in vitro invasion of human glioblastoma cells by urokinase-type plasminogen activator receptor antibody. Cancer Research 53 4143-4147.

Nguyen DH, Catling AD, Webb DJ, Sankovic M, Walker LA, Somlyo AV, Weber MJ \& Gonias SL 1999 Myosin light chain kinase functions downstream of Ras/ERK to promote migration of urokinase-type plasminogen activator-stimulated cells in an integrin-selective manner. Journal of Cell Biology 146 149-164. (https://doi.org/10.1083/ jcb.146.1.149)

Novak ML, Bryer SC, Cheng M, Nguyen MH, Conley KL, Cunningham AK, Xue B, Sisson TH, You JS, Hornberger TA, et al. 2011 Macrophagespecific expression of urokinase-type plasminogen activator promotes skeletal muscle regeneration. Journal of Immunology 187 1448-1457. (https://doi.org/10.4049/jimmunol.1004091)

Nusrat AR \& Chapman HA, Jr 1991 An autocrine role for urokinase in phorbol ester-mediated differentiation of myeloid cell lines. Journal of Clinical Investigation 87 1091-1097. (https://doi.org/10.1172/ JCl115070)

Okunishi K, Sisson TH, Huang SK, Hogaboam CM, Simon RH \& PetersGolden M 2011 Plasmin overcomes resistance to prostaglandin E2 in fibrotic lung fibroblasts by reorganizing protein kinase A signaling. Journal of Biological Chemistry 286 32231-32243. (https://doi. org/10.1074/jbc.M111.235606)

Ossowski L \& Aguirre-Ghiso JA 2000 Urokinase receptor and integrin partnership: coordination of signaling for cell adhesion, migration and growth. Current Opinion in Cell Biology 12 613-620. (https://doi. org/10.1016/s0955-0674(00)00140-x)

Ossowski L, Biegel D \& Reich E 1979 Mammary plasminogen activator: correlation with involution, hormonal modulation and comparison between normal and neoplastic tissue. Cell 16 929-940. (https://doi. org/10.1016/0092-8674(79)90108-9)

Raghu H, Lakka SS, Gondi CS, Mohanam S, Dinh DH, Gujrati M \& Rao JS 2010 Suppression of UPA and UPAR attenuates angiogenin mediated angiogenesis in endothelial and glioblastoma cell lines. PLOS ONE $\mathbf{5}$ e12458. (https://doi.org/10.1371/journal.pone.0012458)

Robker RL \& Richards JS 1998 Hormone-induced proliferation and differentiation of granulosa cells: a coordinated balance of the cell cycle regulators cyclin D2 and p27Kip1. Molecular Endocrinology 12 924-940. (https://doi.org/10.1210/mend.12.7.0138)

Rodgers RJ \& Irving-Rodgers HF 2010 Formation of the ovarian follicular antrum and follicular fluid. Biology of Reproduction 82 1021-1029. (https://doi.org/10.1095/biolreprod.109.082941)

Rossi FW, Prevete N, Rivellese F, Napolitano F, Montuori N, Postiglione L, Selleri C \& De Paulis A 2016 The urokinase/urokinase receptor system in mast cells: effects of its functional interaction with fMLF receptors. Translational Medicine@ UniSa 15 34-41.

Rueda CM, Jackson CM \& Chougnet CA 2016 Regulatory T-cell-mediated suppression of conventional T-cells and dendritic cells by different cAMP intracellular pathways. Frontiers in Immunology 7 216. (https://doi. org/10.3389/fimmu.2016.00216)

Ryan KE, Casey SM, Canty MJ, Crowe MA, Martin F \& Evans AC 2007 Akt and Erk signal transduction pathways are early markers of differentiation in dominant and subordinate ovarian follicles in cattle. Reproduction 133 617-626. (doi:10.1530/REP-06-0130)

Spirli C, Okolicsanyi S, Fiorotto R, Fabris L, Cadamuro M, Lecchi S, Tian X, Somlo S \& Strazzabosco M 2010 ERK1/2-dependent vascular endothelial growth factor signaling sustains cyst growth in polycystin-2 defective mice. Gastroenterology 138 360.e7-371.e7. (https://doi.org/10.1053/j. gastro.2009.09.005)

Stepanova V, Jayaraman PS, Zaitsev SV, Lebedeva T, Bdeir K, Kershaw R, Holman KR, Parfyonova YV, Semina EV, Beloglazova IB, et al. 2016 Urokinase-type plasminogen activator (UPA) promotes angiogenesis by attenuating proline-rich homeodomain protein $(\mathrm{PRH})$ transcription factor activity and de-repressing vascular endothelial growth factor (VEGF) receptor expression. Journal of Biological Chemistry 291 15029-15045. (https://doi.org/10.1074/jbc.M115.678490)

Stryjek-Kaminska D, Piiper A \& Zeuzem S 1995 EGF inhibits secretagogueinduced cAMP production and amylase secretion by Gi proteins in pancreatic acini. American Journal of Physiology 269 G676-G682. (https://doi.org/10.1152/ajpgi.1995.269.5.G676)

Sun HJ, Liu TY, Zhang F, Xiong XQ, Wang JJ, Chen Q, Li YH, Kang YM, Zhou YB, Han Y, et al. 2015 Salusin-beta contributes to vascular remodeling associated with hypertension via promoting vascular smooth muscle cell proliferation and vascular fibrosis. Biochimica et Biophysica Acta 1852 1709-1718. (https://doi.org/10.1016/j. bbadis.2015.05.008)

Takahashi H, Honma M, Miyauchi Y, Nakamura S, Ishida-Yamamoto A \& lizuka H 2004 Cyclic AMP differentially regulates cell proliferation of normal human keratinocytes through ERK activation depending on the expression pattern of B-Raf. Archives of Dermatological Research 296 74-82. (https://doi.org/10.1007/s00403-004-0478-z)

Taniguchi F, Harada T, Deura I, Iwabe T, Tsukihara S \& Terakawa N 2004 Hepatocyte growth factor promotes cell proliferation and inhibits progesterone secretion via PKA and MAPK pathways in a human granulosa cell line. Molecular Reproduction and Development 68 335-344. (https://doi.org/10.1002/mrd.20076)

Tilly JL \& Johnson AL 1987 Presence and hormonal control of plasminogen activator in granulosa cells of the domestic hen. Biology of Reproduction 37 1156-1164. (https://doi.org/10.1095/biolreprod37.5.1156)

Tong G, Meng Y, Hao S, Hu S, He Y, Yan W \& Yang D 2017 Parathyroid hormone activates phospholipase $\mathrm{C}$ (PLC)-independent protein kinase $\mathrm{C}$ signaling pathway via protein kinase A (PKA)-dependent mechanism: a new defined signaling route would induce alternative consideration to previous conceptions. Medical Science Monitor 23 1896-1906. (https:// doi.org/10.12659/msm.903699)

Van Kolen K, Dautzenberg FM, Verstraeten K, Royaux I, De Hoogt R, Gutknecht E \& Peeters PJ 2010 Corticotropin releasing factor-induced ERK phosphorylation in att20 cells occurs via a cAMP-dependent mechanism requiring EPAC2. Neuropharmacology 58 135-144. (https:// doi.org/10.1016/j.neuropharm.2009.06.022)

Vassalli JD \& Belin D 1987 Amiloride selectively inhibits the urokinasetype plasminogen activator. FEBS Letters 214 187-191. (https://doi. org/10.1016/0014-5793(87)80039-x)

Vuchak LA, Tsygankova OM, Prendergast GV \& Meinkoth JL 2009 Protein kinase $\mathrm{A}$ and B-Raf mediate extracellular signal-regulated kinase 
activation by thyrotropin. Molecular Pharmacology 76 1123-1129. (https://doi.org/10.1124/mol.109.060129)

Walia MK, Ho PM, Taylor S, Ng AJ, Gupte A, Chalk AM, Zannettino AC, Martin TJ \& Walkley CR 2016 Activation of PTHrP-cAMP-CREB1 signaling following p53 loss is essential for osteosarcoma initiation and maintenance. eLife 5 e13446. (https://doi.org/10.7554/eLife.13446)

Wu F, Catano M, Echeverry R, Torre E, Haile WB, An J, Chen C, Cheng L, Nicholson A, Tong FC, et al. 2014 Urokinase-type plasminogen activator promotes dendritic spine recovery and improves neurological outcome following ischemic stroke. Journal of Neuroscience 34 14219-14232. (https://doi.org/10.1523/JNEUROSCI.5309-13.2014)

Yang P \& Roy SK 2004 Follicle stimulating hormone-induced DNA synthesis in the granulosa cells of hamster preantral follicles involves activation of cyclin-dependent kinase-4 rather than cyclin D2 synthesis. Biology of Reproduction 70 509-517. (https://doi.org/10.1095/ biolreprod.103.023457)
Zhang Y, Yang J, Yang J, Li J \& Zhang M 2019 CREB activity is required for epidermal growth factor-induced mouse cumulus expansion. Molecular Reproduction and Development 86 1887-1900. (https://doi. org/10.1002/mrd.23285)

Zhou J, Kwak KJ, Wu Z, Yang D, Li J, Chang M, Song Y, Zeng H, Lee LJ, Hu J, et al. 2018 PLAUR confers resistance to gefitinib through EGFR/PAKT/survivin signaling pathway. Cellular Physiology and Biochemistry 47 1909-1924. (https://doi.org/10.1159/000491071)

Received 24 March 2020

First decision 23 April 2020

Revised Manuscript received 3 September 2020

Accepted 10 September 2020 